\title{
The Sustainable Development of Water Resources
}

\author{
R. Warren Flint
}

Five E's Unlimited, Washington, D.C.

$\mathrm{W}$ ater resources management is one of the most important challenges the world faces. It is difficult to think of a resource more essential to the health of human communities or their economies than water. Humans cannot live for more than several days without water, shorter than for any source of sustenance other than fresh air. In meeting their demand for water, societies extract vast quantities from rivers, lakes, wetlands, and underground aquifers to supply the requirements of cities, farms, and industries.

The summer of 2002 in the United States will be remembered for Americans from coast to coast going through one of the worst droughts in decades. While experts discussed the links between water shortages, erratic weather conditions, and population growth, there is also evidence that the way we grow-development patterns-can exacerbate problems with both water quality and quantity. And ironically, water supply is no longer just a western issue in the United States. We are drinking, irrigating, and using water faster than precipitation can replenish groundwater from the Great Plains to the Chicago suburbs to the Florida Everglades.

There is also growing recognition that functionally intact and biologically complex freshwater ecosystems provide many economically valuable commodities and services to society (ecosystem services) beyond simply direct water supply. These services include flood control, transportation, recreation, purification of human and industrial wastes, habitat for plants and animals, and production of fish and other foods and marketable goods. These ecosystem benefits are costly and often impossible to replace when aquatic systems are degraded.
Deliberations about water allocation should therefore, always include provisions for maintaining the integrity of freshwater ecosystems, including the need to maintain minimum in-stream flows and to anticipate the impact of hydrologic modifications on downstream environments (Flint et al. 1996). Otherwise, we have few safeguards that will protect the systems that sustain us.

Besides being an integral part of the ecosystem, water is a social and economic good. Demand for water resources of sufficient quantity and quality for human consumption, sanitation, agricultural irrigation, and manufacturing will continue to intensify as populations increase and as global urbanization, industrialization, and commercial development accelerates (Flint and Houser 2001). Water runs like a river through our lives, touching everything from our vigor and the fitness of natural ecosystems around us to farmers' fields and the production of goods we consume. It is critical that efforts intended to be sustainable fully consider the health and operation of aquatic ecosystems and that the environmental value of watersheds be recognized when making economic and social decisions on water allocation and use.

\section{Why Be Concerned About Water Quantity and Quality?}

In total, less than three-tenths of $1 \%$ of Earth's freshwater is in the lakes and rivers that have served as the major sources of water through most of human history (Adler 2002), but societies worldwide have not always appreciated this easily accessible freshwater and the need to protect it. Thus, water 
Table 1. Why Be Concerned About Our Water Resources?

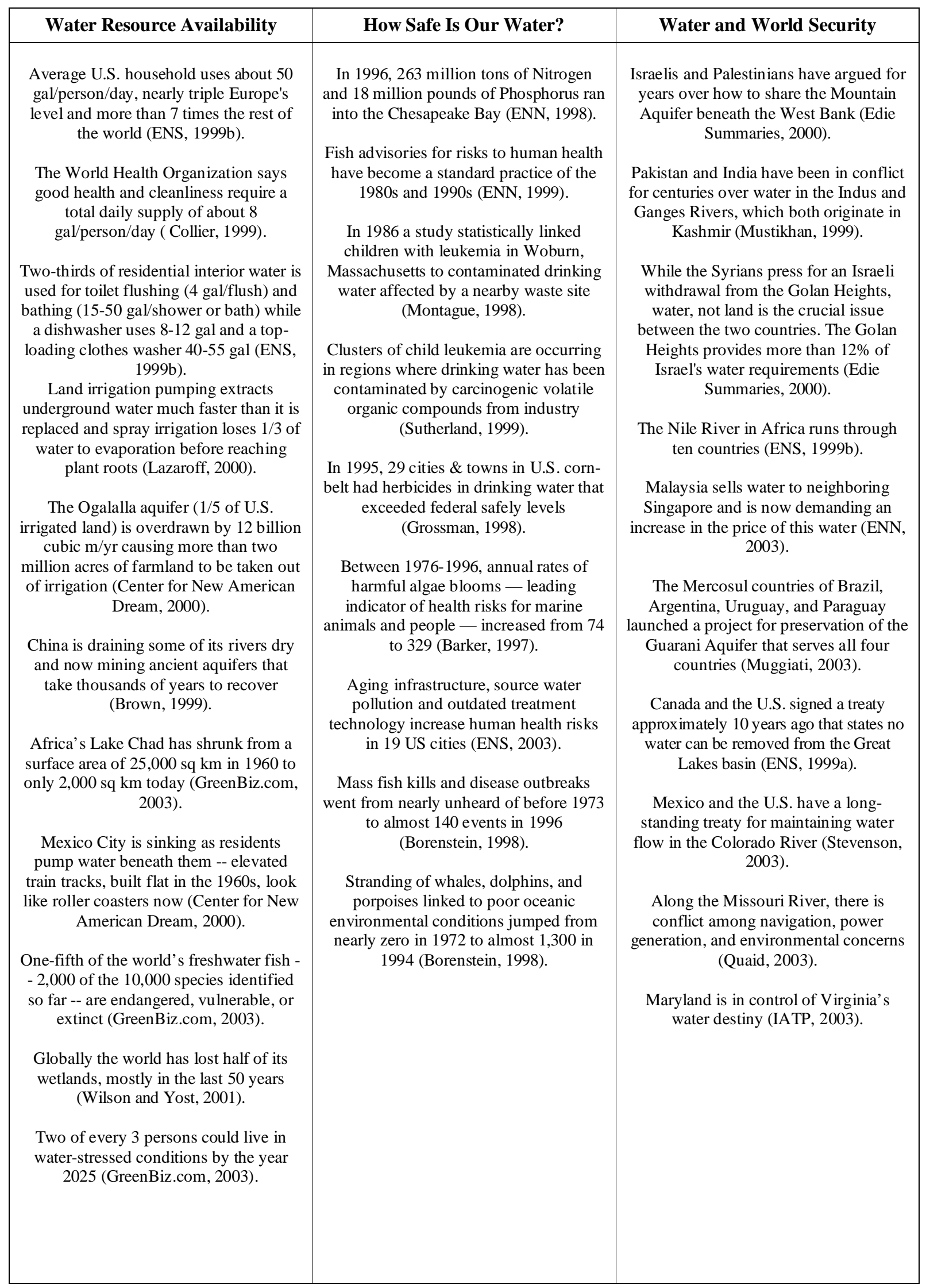


consumption has nearly doubled since 1950 (UNESCO 2003), and much of the world suffers greatly from inadequate access to potable water. About 20\% of the Earth's population of 6.2 billion lacks access to safe drinking water (Hall 2003). According to the United Nations, more than 200 million people every year suffer from water-related diseases, and about 2.2 million of them - mostly the poor-die.

The demand for water resources is continuing to increase. This increase is being driven not only by a growing world population but also by the aspirations of that population for an ever increasing standard of living (Bartlett 1999). At the same time, the capacity of the planet to meet this demand is in decline because of over-harvesting, inappropriate agricultural practices, and pollution, to name just a few. These impacts on Earth are occurring because humans are not in line with the way the natural world functions.

Currently a large proportion of the world's population is experiencing water stress (Table 1). Rising population demands for water from irrigation (70\% of all water uses), industrial (20\%), and residential (10\%) uses greatly outweigh greenhouse warming affects on world water supplies (Vorosmarty et al. 2000). Likewise, humans use more than $50 \%$ of the available freshwater in our world, $60 \%$ of which is wasted, leaving less than half for all other life forms on Earth. The average quarter-pound hamburger requires 616 gallons of water to create its meat; the cheese requires 56 gallons; and the making of the bun 25 gallons of water (Ryan 1997). The average U.S. household uses about 50 gallons per person per day, a rate more than seven times the per capita average in the rest of the world and nearly triple Europe's level. Yet the World Health Organization says good health and cleanliness require a total daily supply of about 8 gallons per person per day (Table 1).

Other signs are just as frightening (Table 1). In 1986, a study statistically linked children with leukemia in Woburn, Massachusetts to contaminated drinking water affected by a waste site nearby. A study released in 1995 has shown that herbicides in drinking water exceed federal safety levels in 29 cities and towns in the U.S. corn-belt. Israelis and Palestinians have argued for years over how to share the Mountain Aquifer, which lies beneath the West Bank. Pakistan and India have engaged in conflict for centuries over water rights to the Indus and Ganges Rivers.

Society is "hitting the limits" or hitting the wall of a funnel, as in The Natural Step (Robert 1991; Gips 1998), in its never-ending use of natural resources and production of waste. The situation of the people on Earth can be viewed as a funnel with ever diminishing room to maneuver. Life-support systems for our continued existence on the planet are in decline. At the same time, the global population and global demand for these resources are increasing, leading us to "hit the wall" of the funnel. Increasing water shortages or inequitable access to safe water can cause poverty and environmental degradation that can lead to global hunger, resulting in civil unrest and human conflict. With conflict comes regional and national disputes, even war, that can best be alleviated by the sustainable use of these resources.

\section{How Do We Act Sustainably?}

Society consistently faces issues related to economy, environment, and fairness among people. Each of these human concerns is in some way impacted by the forces that drive the natural world. However, development models intended to tackle societal problems have traditionally taken a piecemeal, singular approach, addressing issues of economics, environment, or social health, sometimes in isolation from one another (Flint and Danner 2001). For example, socio-economic systems often become caught up in the adversarial "economy versus environment” debate and begin operating in a linear direction: taking resources from the Earth, making them into products, and throwing them away to produce large amounts of waste (take-makewaste). This process leads to communities being unsustainable.

Sustainable development is the centerpiece and key to water resource quantity and quality, as well as national security, economic health, and societal well-being. The word sustainability implies the ability to support life, to comfort, and to nourish. For all of human history, the Earth has sustained human beings by providing food, water, air, and shelter. Sustainable also means continuing without lessening (Flint et al. 2002). Development means improving or bringing to a more advanced state, such as in our economy. 
Thus, sustainable development can mean working to improve human's productive power without damaging or undermining society or the environment- that is, progressive socio-economic betterment without growing beyond ecological carrying capacity: achieving human well-being without exceeding the Earth's twin capacities for natural resource regeneration and waste absorption (Flint 2003). By acting under the principles of sustainable development, our economic desires/demands become accountable both to an ecological imperative to protect the ecosphere and to a social equity imperative to create equal access to resources and minimize human suffering. These requirements are the foundation of sustainable development as represented by the three circle model (principle elements) of sustainability in Figure 1. These three elements interact with each other so continuously that we cannot make decisions, make policy, manufacture, consume, essentially do anything without considering the effects and costs upon all three simultaneously. Each circle (sustainability principle) is defined as follows (Flint 2003):

Economic Vitality (Compatible with Nature)

is development that protects and/or enhances natural resource quantities through improvements in management practices/policies, technology, efficiency, and changes in life-style.

Ecologic Integrity (Natural Ecosystem Capacity)

is understanding natural system processes of landscapes and watersheds to guide design of sound economic development strategies that preserve these natural systems.

\section{Sustainability Model}

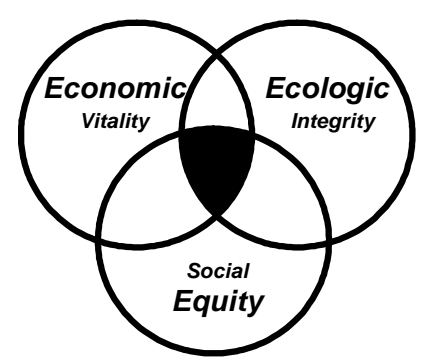

Figure 1. This conceptual model of sustainable development illustrates the relationship among economic, ecologic, and social issues of concern in decision-making. The black overlap of the three circles represents the nexus of connection among issues.
Social Equity (Balancing the Playing Field) is guaranteeing equal access to jobs (income), education, natural resources, and services for all people: total societal welfare.

Carrying out activities that are sustainable requires simultaneous, multi-dimensional thinking about the consequences of present actions in a cause and effect pattern on future public and environmental health through examination of the connections among environmental, economic, and social concerns when we make choices for action.

In understanding the three overlapping circles, it is also critical to recognize there is "directionality" to each circle's dependence on the others (Figure 2). It is true that all life depends on natural resources (Wackernagel and Rees 1996). However, economy and society are no less important to humanity than ecology. Rather, there is a "directionality" of dependence. Sustainable development does not try merely to attain a "balance" between economics and environment as if they were two distinct entities. Rather, it considers directionality, where economic and cultural activities are integrated into natural processes in a cyclic fashion so as not to degrade the environment upon which economic prosperity and social stability rest.

For example, consider the production of electricity. To have a prosperous economy, society demands the continued and added production of electricity. For electricity to be produced to power our economies, society must both develop the appropriate technologies and regulate its demand for this

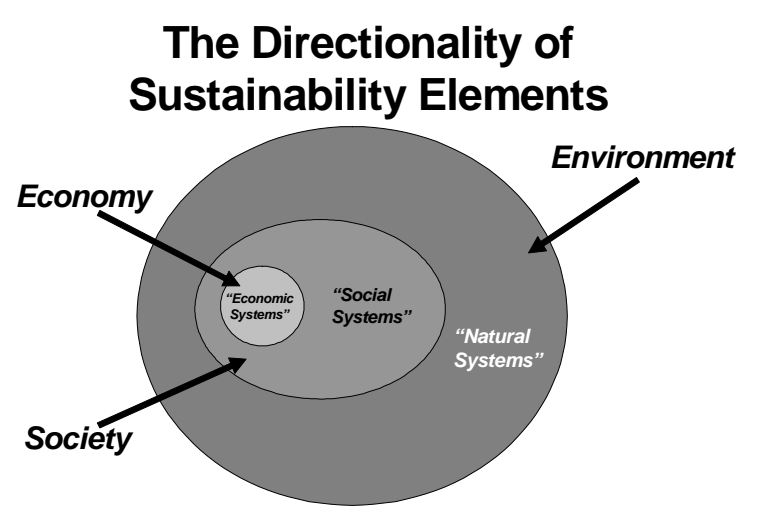

Figure 2. The directionality of each sector element's dependence upon the other elements of the sustainability model, where financially viable and cultural activities are integrated into natural processes in a cyclic fashion so as not to degade the environment upon which economic prosperity and social stability rest. 
electricity so that the supply of water (environmental issues) used for electrical production is consumed in a sustainable way. Electricity requires both sources of cooling water in traditional fossil-fuel power-production plants and the continuous supply of flowing water in hydropower production facilities. Thus, the directionality of this scenario (Figure 2) is that our economic ventures cannot be driven by electricity if society does not provide the human capital resources and there are not adequate supplies of freshwater. In a feedback process, the use of water as a natural resource for making electricity must not impair other users of the water by the activities of power production releasing polluted or in other ways degraded water as an output.

In sum, the existence of economies is based solely on the existence of societies and their capacity to add value to natural resources. Furthermore, society cannot exist without an acceptable environment and the resources that the environment provides for basic human needs. This is the directionality of water resources sustainability (Figure 2). In terms of a three-stage rocket:natural capital (environment) is built orenhanced to power human capital (society) propelling financial capital (economy) through the engines of society and the resources to which society adds value.

\section{Evaluation Strategy to Determine Water Resource Sustainability}

Current piecemeal and consumption-oriented approaches to water policy cannot solve the problems confronting our increasingly complex world. Traditionally, we apply a sectorial approach to the evaluation of water (e.g., the present conflict over the water resources of the Missouri River among navigation, power generation, and environmental concerns) (Quaid 2003). The only equitable solution to these problems, however, is a systemic approach that considers ecological integrity and the ecosystem services that natural resources can provide. By considering the ecosystem services that water resources offer, our deliberations become able to more fully integrate the social and economic issues

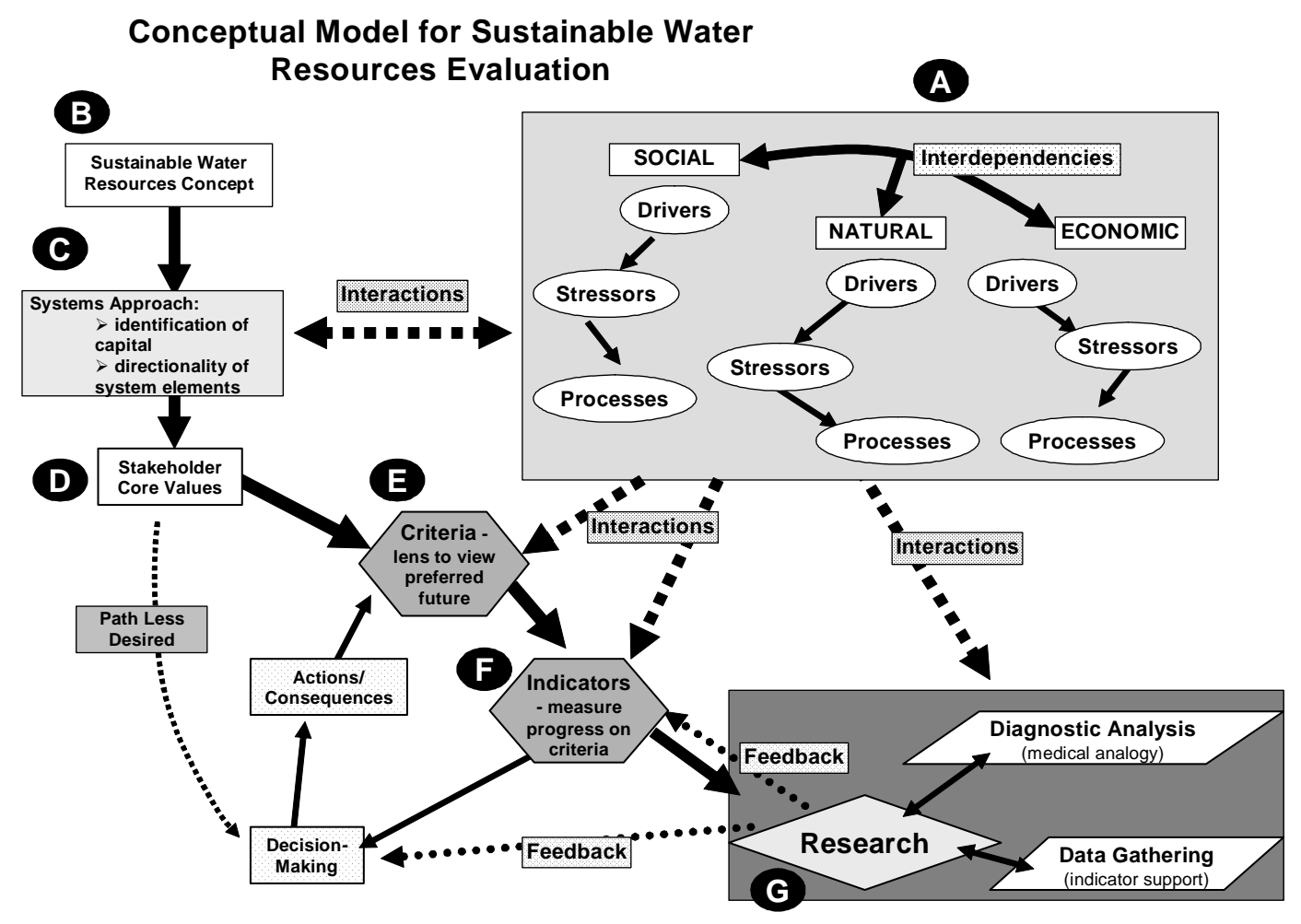

Figure 3. Systemic framework for evaluating water resources through the development of criteria and indicators. (A) illustrates the systems approach. (B) shows the development of a conceptual view of sustainable water resources. (C) defines water resources "capital" and assesses directionality of issues. (D) elaborates the sustainability goals of stakeholders. (E) develops criteria to judge water resource sustainability. (F) identifies indicators to measure sustainability. (G) demonstrates the research support required by this evaluation strategy. 
that would elude us if our only concern was the environmental aspects of water.

A conceptual framework of a system's perspective to evaluating water resources through development of criteria and indicators could be represented by the theoretical model in Figure 3. A systems perspective should be used to understand the interactions among the various forms of environmental, social, and economic capital and the processes that most directly affect them in order to guide better decision-making for the sustainable development of water resources (Figure 3A ). Using the principles of sustainable development outlined above, the following illustrates the steps one might take in pursuing the guidance of this conceptual framework.

\section{Develop a conceptual view of sustainable water resources (Figure $3 B$ ).}

Because there is fear that too many different perspectives will interfere with the overall goal of developing a strategy, groups of people often avoid the discussion of sustainability in their dialogue about how best to manage resources. Others contend that this discussion is necessary to provide everyone with the perspective of others and to honor the ideas of all who are participating in the discussion. Having this discussion can produce a point of reference that is absolutely necessary for there not to be a constant "moving target" to the focus of discussions. For example, an agreeable statement might include the following: "The sustainable development of water resources is a multi-dimensional way of thinking about the connections or interdependencies among natural, social, and economic systems in the use of water." This view suggests that attempts to achieve economic vitality are done in the context of the enhancement and preservation of ecological integrity, social well-being, and security for all (Conceptual Model group of the Sustainable Water Resources Roundtable 2003). The sustainable development of water resources:

- involves policies, plans, and activities that improve equality of access and quality of life for all;

- recognizes the limits and boundaries beyond which ecosystem behavior might change in unanticipated ways;

- advocates consideration of spatial scales, recognizing that interactions occur among different geographical ranges — globally, nationally, regionally, and locally; and

- challenges us to look to the future, and to fully assess and understand the implications of the decisions made today on the lives and livelihoods of future generations and the natural ecosystems upon which they will rely.

2. Categorize the key forms of natural, social, and economic capital that need to be sustained to identify stakeholder core values with regard to water (Figure $3 \mathrm{C}$ ).

Capital refers to the condition and capacity of any stock, inventory, or accumulation of materials or resources found in economic, environmental, or social systems yielding a flow of goods and services that possess a value directly, or may be devoted to the production of other goods (Daly and Cobb 1994; Wackernagel and Rees 1996b). For example, natural capital refers to any stock or inventory of natural resources found in our environment that yields a flow of valuable goods and services into the future (e.g., an underground water aquifer or fish stock that can provide a harvest or flow).

Natural capital might include the following: surface/ground water quantity and quality; precipitation/climate trends; biodiversity; fisheries production; wildlife habitat; energy production; watershed/ecosystem services; watershed functional integrity; ecological infrastructure; land-use conversion; or environmental aesthetics (tourism quality). Social capital could include: subsistence rights; drinking water supply; community capacity; fiscal spending ability; regulatory framework (governance capability/resource policies); resource policies; institutional infrastructure; access to knowledge; quality of life; equal resource access; beauty and play; or security. Likewise, economic capital might include: commercial/recreational fisheries; forestry production; energy supply; agricultural production (irrigation); industrial use; resource ownership; true-cost pricing; waste as resource; value-added production; transportation support; waste treatment; flood control; or tourism/ recreation.

\section{Develop achievable goals for water resource sustainability that reflect the various stakeholder core values (Figure 3D).}


Goals can be used to begin the in-depth, integrated assessment of watershed resources that lead to sustainability. These goals, which will represent stakeholder core values, should be formulated to address a number of fundamental principles that underlay the conservation, protection, remediation, and longevity of water resources. Such goals might include:

- Provide safe and equal access to water supplies needed for domestic, municipal, industrial, agricultural, and hydropower uses.

- Provide sufficient water quality/quantity to support ecological function.

- Measure and protect against biological and ecological degradation in aquatic ecosystems and restore integrity of degraded ecosystems.

- Reduce discharges of pollutants into surface waters and eliminate contamination and overconsumption of groundwater.

- Prevent human health risks due to the spread of waterborne diseases, water contamination, and hostile actions.

- Prevent physical modifications from land use/ cover changes or hydrologic disturbances within watersheds that cause risks to humans, natural systems, and property.

- Encourage a holistic, watershed-based approach to evaluating all water resource issues that is participatory, democratic, equitable, and socioeconomically sensitive.

- Develop appropriate water resource policies; institutional arrangements and structures; financial systems; and legal and regulatory authorities to achieve integrated water resources management.

\section{Define criteria that establish the conditions to protect and maintain all the perceived beneficial uses of water assets (Figure 3E).}

Following the development of goals all stakeholders can agree to concerning their efforts at sustaining water resources, criteria should be identified that establish the conditions deemed necessary to protect and maintain all the perceived beneficial uses of water assets. In essence, criteria provide a "lens" through which to evaluate the preferred future status of water (i.e., characteristics that best define water sustainability) (Flint et al. 2002).
The definition of criteria is extremely important in this conceptual framework because, by choosing to develop criteria, stakeholders and managers are deciding to pursue a specific path. This path differs from making decisions based upon expressed stakeholder values (Figure 3). The choice of appropriate criteria can guide communities toward their anticipated outcomes, as defined by their goals, and introduce a process for establishing expected outcomes as well as a means of measuring progress toward those outcomes. Such criteria for water resources might include:

a) The quantity of groundwater is monitored, and these reserves are protected from pollution and depletion.

b) The water resource in question meets the quality and quantity for "designated uses."

c) Fish taken from recreational and commercial fisheries are not contaminated.

d) Fish populations and other wildlife that rely on aquatic habitats and on the assemblages of species that inhabit aquatic ecosystems are healthy according to standards established by science.

e) In-stream flows are enhanced and protected for environmental benefits.

f) No actions are taken that will harm or threaten endangered species.

g) Industrial and municipal point sources of pollution are less than the Total Maximum Daily Load (TMDL) standards for the water resource in question.

h) Non-point sources of polluted runoff and erosion from intensive land uses are monitored and sources eliminated through the use of best management practices.

i) Watershed-wide assessment programs exist to identify the full range of pollution sources within the watershed, and they use the TMDL approach or its equivalent to integrate a watershed approach.

j) Decisions on water quantity and quality are considered concurrently because they pose potentially contradictory challenges for water resource management and protectionwhen evaluated separately.

k) Water conservation strategies are regularly relied upon for reducing waste of water, using water more efficiently, and meeting new demands upon existing water supplies. 
l) Holistic, integrated assessment strategies with regards to water allocation and transfers are adapted to limit impact on the economic stability of rural communities.

\section{Define indicators to measure sustainability progress (Figure 3F).}

Communities need a believable means of setting sustainability goals and then determining the degree to which these are reached. Policy-makers also need "early warning signals" of poor performance that can enable appropriate adjustments. After a consensus is developed with regard to criteria that describe the future longevity of healthy water resources, indicators to measure sustainability can be defined. The role of an indicator is to make complex systems understandable and perceptible (tangible). It clarifies a problem or condition by showing how well a system is working. Indicators point the way and mark progress toward a community vision of sustainable development. An indicator creates a snapshot of a resource's economic, social, and environmental system conditions and provides the opportunity to better understand past trends so that the decision-makers can influence future directions of development. A good indicator alerts one to a problem before it gets too bad, and it helps you recognize what needs to be done to fix the problem.

An effective indicator or set of indicators helps a community determine where it is, where it is going, and how far it is from chosen sustainability criteria that reflect established water resource criteria. "Where Do We Want To Be" will reveal the goals or issues that are important. Indicators of sustainability examine a resource's long-term viability based on the degree to which its economic, environmental, and social systems are efficient and integrated in striving to reach community goals. Before time is spent gathering and reporting data for an indicator, it should be compared to the community's perception of sustainability to make sure that the chosen indicator is measuring the right thing. If data do not exist for some chosen indicators, try to define the best indicators and only settle for less as an interim step while developing data sources for better indicators.

Indicators of sustainability are not the traditional indicators of economic success or environmental quality. Because the achievement of sustainability requires a more integrated view of the world, indicators of sustainability should link economy, environment and society as well as point to where these links are weak. For example, an economic indicator that does not include environmental and social effects will not help move water resource protection in a sustainable direction (e.g., the Missouri River conflict). Likewise, an environmental indicator that does not take into account economic and social impacts will not provide adequate insight into the best way to improve water resource health and vitality. A perfect example of what is being said here is the following: when the Exxon Valdez ran aground, the spilled oil killed millions of animals and cost millions of dollars to clean-up. The jobs created from clean-up activities made the U.S. Gross National Product (GNP), a much-relied upon national indicator, go up (Flint and Houser 2001). In this case, using the GNP as an indicator suggests that we should get more oil tankers to run into rocks more often.

Indicators will tell decision-makers and society in general, how we are doing toward the achievement of sustainable use with regards to water resources. Indicators represent standards for measuring characteristic criteria (conditions) of sustainability, and they are as varied as the types of systems they monitor. However, there are certain characteristics that effective indicators have in common:

- Relevant to sustainability and link economy, society, and environment

- Developed and accepted by the people in the community

- Understandable to the community at large and reflect stakeholder's concerns: important to the lives of the audience

- Attractive to the media and can be used to monitor, analyze, and communicate local trends.

- Accurately measure the issue or goal in a scientifically defensible way

- Focus on long-range view: reliable up to two decades or more

- Flexible enough to incorporate new scientific information and changing public perceptions

- Can be compared to existing and past measures to define trends and identify stresses

- Advance local sustainability, but not at the expense of other regions 
- Measure an appropriate geographic area and/or an appropriate time interval

- Provide early warning of changes

- Can measure movement towards or away from a specified target/goal

- Based on reliable and timely information that is easy to gather at modest cost

- Outcome (results) oriented: focus on measuring achievements instead of efforts or expenditures After identifying key indicators and corresponding databases, we must conduct the exercise of setting benchmarks or targets for each indicator. A target is the threshold used to define sustainability from unsustainable practices. These targets will help identify water resource criteria that are sustainable. Unsustainable criteria are long-term problems for the region of concern.

\section{Research}

From this conceptual framework evolves the need for added research activities (Figure 3G). Such activities are an important form of feedback for social learning and adaptive management. In following the criteria/indicator model, there will probably be a need for system diagnosis to explain undesirable trends that may be shown by indicator measures. Such diagnosis, as characterized by the medical analogy example (Heintz 2003), is a key element in adaptive management processes that should be designed to direct the use of water resources within a sustainable framework and to better help us understand what the system conditions are alerting us to when indicators tell us something is wrong (e.g. high body temperature in humans). With time and continued application of this strategy, a dialogue will also evolve on research needs to address recognized data gaps for identified indicators and to build our understanding of ecosystem processes.

\section{Conclusion}

More than one-sixth of the world's population does not have access to safe water supplies. The potential conflicts from this disparity are frightening. The escalation of a water crisis in the world is due essentially to the unsustainable use and management of water resources and to the destruction of ecosystems such as forests, wetlands, and soil that capture, filter, store, and release water.
Through our evaluation of water resource sustainability, we must not only increase public awareness about the challenges the world is facing in relation to water, but we must also change the way the water issue is perceived: from being a driver of conflict to being a catalyst for collaboration. In doing so, we must not only view sustainability as a problem of science, engineering, or economics; it is also founded on values, ethics, and the equal contributions of different cultures. Additionally, all members of a community have a shared future; they are dependent on each other in ways that are both complex and profound. Thus, ideals of preservation and protection, on the one hand, and of economic vitality and opportunity, on the other, are not in conflict. Rather, in a sustainable future, they are linked together. Moreover, we recognize our limited ability to see needs of the future; therefore, any attempt to define sustainability should remain as open and flexible as possible through the use of adaptive management.

In summary, it might be helpful to consider the following. Although we need only about 1.5 to 2.0 quarts of water per person per day to stay alive, the total human population needs the balance of the water resources in the atmosphere, oceans, ice, wetlands, and other aquatic systems to buffer emergencies (Adler 2002). These masses of water provide crucial functions by absorbing and redistributing energy and waste products from life forms. They shield us from the atmosphere's fluctuations in gaseous content, and they offer transportation and provision of conversion sites for nutrients in food chains. If such resources are spoiled, conditions for human life will inevitably deteriorate. A person's 1.5 to 2.0 quarts of water alone will not save them because we do not know specific quantities that constitute a sufficient buffer. Policies must reflect and be built on the conservative natural distribution and use of the world's total water resources.

\section{Author Information}

Warren Flint obtained his Ph.D. in Ecology \& Limnology in 1975 from the University of California at Davis. Dr. Flint serves as principal for the firm Five E's Unlimited (http:www.eeeee.net). Through consulting work, he provides international leadership in developing research, management, policy protocol, and education strategies toward achieving sustainable development goals, as defined by governments, 
corporations, academic institutions, communities, and nongovernmental organizations. He assists regions in creating authentic choices and providing effective responses to economic decline, environmental degradation, and community disintegration. Dr. Flint is effective at applying interdisciplinary knowledge learned from science toward real world water resource problems, land-use issues, and corresponding economic development. He is a member of the Sustainable Water Resources Roundtable. As a sustainable development specialist, much of Dr. Flint's consultant work over the last 10 years has centered on promoting sustainable community improvements by working with groups to seek common-ground solutions in their integration of economic, environmental, and social equity concerns. Contact Information: Dr. R. Warren Flint, Five E’s Unlimited, 28 Randolph Place, NW, Washington, DC 20001 USA; Telephone: (202) 232-4591; E-mail: rwflint@eeee.net.

\section{References}

Adler, R. W. 2002. Fresh Water. In Stumbling Toward Sustainability, edited by J. C. Dernbach. Washington, DC: The Environmental Law Institute.

Barker, R. 1997. And the Waters Turned to Blood. New York: Simon and Schuster.

Bartlett, A. A. 1999. Colorado's Population Problem. Population Press 5(6): 8-9.

Borenstein, S. 1998. Coastal Waters have big problems, Harvard study says. The Buffalo News, 25 August.

Brown, L. 1999. China’s Water Crisis Linked to Global Security. Population Press 5(5): 5.

Center for New American Dream. 2000. [Online]. Available at http://www.newdream.org/monthly/aug00.html.

Collier, C. 1999. Save Some for Tomorrow. Environment News Service. [Online]. Available at http://ens.lycos.com/ewire/July99/20july9903.html.

Daly, H. E. and J. B. Cobb. 1994. For the Common Good. Boston: Beacon Press.

Edie Summaries. 2000. Israel: Water Not Land is Key to Shepherdstown Talks. [Online]. Available at http:// www.edie.net/news/Archive/2223.html.

ENN (Environmental News Network). 1998. Heavy Rains Drive Home Pollution Problem. [Online]. Available at http:/ /www.enn.com/archives/1998/02/020698/yotostry.asp.

1999. Beware, Don't Eat the Fish. [Online]. Available from http://www.enn.com/enn-news-archive/1999/ 03/032999/croaker_2349.asp.

2003. Malaysian Leader Defends Government's Campaign Against Singapore Over Water Use. [Online]. Available at http://www.enn.com/news/2003-0718?s_6707.asp.

ENS (Environment News Service). 1999a. Canada, U.S. Consider Great Lakes Water Export Ban. [Online]. Available at http://ens.lycos.com/ens/aug99/1999L-08-24-06.html. 1999b. Growing Population Faces Shrinking Water Supply. [Online]. Available at http://ens.lycos.com/ ens/jul99/1999L-07-20-01.html.

. 2003. Threats Rising for U.S. Public Water Supplies. [Online]. Available at http://ens-news.com/ens/ jun2003/2003-06-11-10.asp.

Flint, R. W. 2003. Sustainable Development: What does sustainability mean to the individual in the conduct of their life and business. In Handbook of Development Policy Strategies, edited by G. M. Mudacumura. New York: Marcel Dekker, Inc.

Flint, R. W., S. B. Sterrett, W. G. Reay, G. F. Oertel, and W. M. Dunstan. 1996. Agricultural and environmental sustainability: A watershed study of Virginia's Eastern Shore. In Watershed '96 A National Conference on Watershed Management, edited by Tetra Tech. Washington, DC: Water Environment Federation.

Flint, R. W. and M. J. E. Danner. 2001. The nexus of sustainability and social equity. International Journal of Economic Development 3(2). [Online]. Available at http:// spaef.com/IJEC_PUB/v3n2.html.

Flint, R. W. and W. L. Houser. 2001. Living a Sustainable Lifestyle for Our Children's Children. Campbell, CA: IUniverse.

Flint, R. W., F. C. Frick, A. Duffy, J. Brittingham, K. Stephens, P. Graham, and C. Borgmeyer. 2002. Characteristics of Sustainable Destination Resort Communities. Resort Municipality of Whistler, BC, Canada. [Online]. Available at http://www.whistlerfuture.com/thinkit/pdfs/ Whistler_Sustainit3.pdf).

Gips, T. 1998. The Natural Step Four Conditions for Sustainability or "System Conditions. Minneapolis, MN: Alliance for Sustainability \& Sustainability Associates.

GreenBiz.com. 2003. Humanity Wages War with Nature for Water. Environmental News Network, New York. [Online]. Available at http://www.enn.com/news/2003-02-05/ s_2417.asp).

Grossman, R. 1998. Can Corporations Be Held Accountable? Part I. Rachel's Environment and Health Weekly 609. [Online]. Available at http://www.rachel.org.

Hall, K. 2003. Tackling World's Water Crisis Could Cost Up To US \$100 Billion a Year. In Environmental News Network [Online]. Available at http://www.enn.com/news/2003-0306/s_3213.asp).

Heintz, T. 2003. Personal communication, May 12, 2003.

Hettena, S. 2003. California Desert Residents Use Water Like There's No Tomorrow - But Tomorrow Is Coming. In Environmental News Network (ENN). [Online]. Available at http://www.enn.com/news/2003-06-11/ s_4917.asp. 


\section{The Sustainable Development of Water Resources}

IATP (Institute for Agriculture and Trade Policy). 2003. Maryland in Control of Virginia's Destiny. US Water Network Publication, 4 April. Minneapolis, MN.

Lazaroff, C. 2000. Growing population faces diminishing resources. In Environment News Service. [Online]. Available at http://ens.lycos.com/ens/jan2000/2000L-01-18-06.html.

Montague, P. 1998. Landfills are Dangerous. Rachel's Environment and Health Weekly. 617: 2. [Online]. Available at http://www.rachel.org.

Muggiati, A. 2003. Four Nations Guard Giant South American Aquifer. In Environment News Service. [Online]. Available at http://ens-news.com/ens/may2003/2003-05-29-03.asp.

Mustikhan, A. 1999. Pakistan Provinces Feud Over Water. In Environment News Service(ENS), 7/28/99. [Online]. Available at http://ens.lycos.com/ens/jul99/1999L-07-28-02.html.

Quaid, L. 2003. Missouri River Ruling Could Hinder Water Quality. In Environmental News Network [Online]. Available at http://www.enn.com/news/2003-07-15/ s_6555.asp.

Robert, K.H. 1991. Educating a Nation: The Natural Step. In Context 28, In Context Institute [Online]. Available at http:// www.context.org/ICLIB/IC28/Robert.htm.
Ryan, J.C. 1997. Stuff - The Secret Lives of Everyday Things. Seattle, WA: Northwest Environmental Watch.

Stevenson, M. 2003. The "Other" Gulf War, Dispute Over Water Rights threatens Environment. In Environmental News Network (ENN). [Online]. Available at http:// www.enn.com/news/2003-05-23/s_4585.asp.

Sutherland, D. 1999. Tug-o-War: Cancer kids vs water pollution. Environment News Service. [Online]. Available at http:// ens.lycos.com/ens/sep99/1999L-09-27-01.html.

UNESCO, 2003. Water for People, Water for Life: The World Water Development Report. World Water Assessment Programme, United Nations, NY. [On-line]. Available at http://ens-news.com/ens/mar2003/2003-03-05-02.asp).

Vorosmarty, C. J., P. Green, J. Salisbury, and R. B. Lammers. 2000. Global water resources: vulnerability from climate change and population growth. Science 289: 284-287.

Wackernagel. M. and W. Rees. 1996. Our Ecological Footprint. Gabriola Island, Canada: New Society Publishers.

Wilson, A. and P. Yost. 2001. Buildings and the environment: the numbers. Environmental Building News, 1 May. 